Вісник Національного університету “Львівська політехніка”.

Серія "Проблеми економіки та управління"

T. 4, № 1, 2020

\title{
ПРОБЛЕМИ ЕКОНОМІКИ
}

УДК 658.153:330.142.26:519.233.5

JEL Classification Code C02, P34

Kh. P. Danylkiv, N. Ye. Hembarska, V. Ya. Havran, I. I. Hrybyk

Lviv Polytechnic National University

\section{ECONOMIC AND MATHEMATICAL MODELING \\ OF THE EFFICIENCY ESTIMATION OF CURRENT USE ASSETS THROUGH CORRELATION AND REGRESSION APPROACH}

http://doi.org//10.23939/semi2020.01.001

(C) Danylkiv Kh. P., Hembarska N. Ye., Havran V. Ya., Hrybyk I. I., 2020

At the current stage of economic reform, the introduction of market-based management methods, there is a growing need for prompt decision-making in the calculation and forecasting of options for possible directions of production activity of individual enterprises. And this is practically impossible to do without the use in analytical study of economic and mathematical methods. The most common in the process of simple economic analysis of the activity of economic systems is the use of correlation-regression analysis.

As part of the author's approach to assessing the efficiency of using working capital at PE "Svit soli" using correlation-regression analysis, the following stages were distinguished: establishing a form of communication and mathematical equation of communication by plotting a correlation dependence between the study year (factor $x$ ) and a certain statistic (factor $y$ ); the coefficient of determination and the correlation coefficient $r$ are calculated and the relationship between factor $x$ and $y$ is estimated; using the Fischer criterion, the probability of 0.95 estimated the adequacy of the accepted econometric model with statistical data; the statistical significance of the parameters of the linear equation with reliability $\mathbf{P}=$ 0.98 was checked by the t-criterion; confidence intervals were found for linear equation coefficients with reliability $P=0.98$.

Considering all the obtained results, PE "Svit soli" is characterized by a solvent and financially sustainable enterprise and is at the peak of its development, as evidenced by the indicators in the following years. On improving the effectiveness of indicators, the following recommendations are proposed to improve them: optimization of supply organization and supplier selection system; ensuring the optimum volume and structure of inventories to ensure a stable production process with minimal inventory maintenance costs; acceleration of the turnover of current assets, in particular the main ways of calculating the volume of stocks and their liquidation; providing a unified methodology for organizing and keeping records of individual components of current assets; introduction of advanced technologies and, as a consequence, increase of labor efficiency; improving the organization of logistics and sales; optimization of sales and credit policy.

Key words: working capital efficiency, correlation-regression analysis, regression model, linear regression, coefficient of determination, econometric model, correlation dependence.

\section{Statement of the problem}

The difficult economic situation, the devaluation of the hryvnia and high inflation cause Ukrainian companies to focus on resolving the issues of ensuring an adequate level of liquidity and solvency. Obtaining a net profit in such circumstances is a true achievement of management and a proof of its success and 


\section{Kh. P. Danylkiv, N. Ye. Hembarska, V. Ya. Havran, I. I. Hrybyk}

professionalism. All these issues depend to a large extent on the management of the working capital of the enterprise. Particular attention is paid to the correlation-regression approach in the process of estimation of the working capital utilization, which makes it possible to analyze the significance of the factors of influence on the result indicator by means of correlation coefficients and construct a regression equation.

\section{Analysis of recent research and publications}

Many domestic and foreign scientists have made significant contributions to the study of approaches to assessing the effectiveness of working capital through correlation-regression analysis. N. P. Karachyna proposes to isolate several factors and construct a regression model using the Ms Exel Analysis Package component [1]. Yu. G. Shvetsov and T. V. Sabelfeld substantiated the use of a correlation matrix taking into account the correlation coefficient between the factors of influence [2]. This approach eliminates multicollinear factors of influence and increases its statistical significance from the regression model. I. M. Vyhivska, V. O. Shevchenko and L. Ya. Shevchenko suggest calculating the regression equation to supplement the calculation of elasticity coefficients for each of the factors to identify their comparative strength and reserves for increasing the resultant index [3]. At the same time A. D. Kryukov believes that it is sufficient to estimate the correlation between net (gross) profit and the indicators of valuation of working capital elements. The latter include absolute figures, specific gravity and turnover ratios [4, c. 139]. Terebukh A. and Lisovska L. developed and calculated economic and mathematical models of optimization of economic decisions according to the data of economic activity of enterprises [5].

Most authors approach the problem of estimating the efficiency of the use of working capital with the help of correlation-regression analysis rather one-sided. In our view, an objective approach requires a comprehensive approach that takes into account not only the regression equation and the nature of the relationship between the factors and the performance indicator, but also the importance of the factors themselves in making management decisions.

\section{The formulation of objectives}

The purpose of the article is to develop an approach to correlation-regression analysis of the effectiveness of working capital; analysis of the economic activity of PE "Svit soli" using the above approach.

The achievement of the goal necessitated the following goals:

- Establish a link form and mathematical link equation by plotting a correlation between the year of study (factor $x$ ) and a specific statistic (factor $y$ ).

- Find estimates of the parameters $a$ and $b$ of the linear linear regression equation: $\hat{y}=a+b x$.

- Calculate the theoretical values of the exponent $y$ and construct a theoretical regression line.

- Calculate the correlation coefficient $r$ and estimate the coupling density between factor $x$ and exponent $y$.

- Calculate the coefficient of determination.

- Using the Fischer criterion, the probability of 0.95 is to estimate the adequacy of the accepted econometric model with statistics.

- Using the $t$-statistic, estimate the significance of the correlation coefficient $r$.

- To check the statistical significance of linear equation parameters with reliability $P=0.98$ by $t$-test.

- Find the confidence intervals for the linear equation coefficients with reliability $P=0.98$.

- Find a point forecast of current assets for 2020, 2025, 2030 year.

\section{Presentation of main materials}

Analyzing the working capital of the enterprise, it is necessary to pay special attention to their dynamics. Since dynamics characterize the development of the phenomenon in time, the analysis of dynamics makes it possible to predict the future level of working capital and on this basis - to determine 
Economic and mathematical modeling of the estimation of efficiency of use of current assets by means of...

the promising directions of enterprise development. One of the main tasks of dynamics analysis is to establish patterns of change in the levels of the phenomenon being studied. In addition to the constant action of systematic and random factors, the level of a number of dynamics is also influenced by circumstances caused by the frequency of oscillations.

The choice of the curve shape largely determines the results of the trend extrapolation (forecasting). The basis for choosing the shape of the curve should be an analysis of the nature of the phenomenon.

In order to identify the main components that affect the value of the working capital of the enterprise, we will conduct a correlation analysis of individual financial indicators of the private enterprise "Svit soli". To determine these dependencies, we perform a correlation-regression analysis [6] and construct an economic-mathematical model [7].

According to the financial statements of the private enterprise "Svit soli" we can distinguish the following factors of influence on working capital $(Y)$ as of the end of the reporting year:

$X_{1}$-income (revenue) from sales of products (goods, services);

$X_{2}-$ net cash flow for the year, thousand UAH;

$$
\mathrm{CF}=\text { Net profit }+ \text { Amortization, }
$$

$X_{3}-$ current liabilities as of year-end, thousand $\mathrm{UAH}$;

$X_{4}$ - retained earnings (uncovered loss) of the enterprise at the end of the year, thousand UAH;

$X_{5}$ - equity as of the end of the year, thousand UAH;

$X_{6}$ - short-term bank loans at the end of the year, thousand UAH;

$X_{7}-$ net profit for the year, thousand UAH;

$X_{8}$ - inflation index for the year, \%;

$X_{9}-$ cost of goods sold (goods, works, services) for the year, thousand UAH;

$X_{10}$ - the cost of labor for the year, thousand UAH;

$X_{11}$ - material expenses for the year, thousand $\mathrm{UAH}$;

$$
\text { Value: } \mathrm{R}^{2}=0.981 \quad \mathrm{P}=0.98 \text {. }
$$

In order to identify the main factors that affect the working capital of the enterprise "Svit soli", we will conduct a correlation analysis of individual financial indicators of the enterprise. MS Excel (Data Analysis/Correlation Add-in) was used for its implementation; the results are presented in Table 1.

Table 1

\section{Outcome indicator and factors for setting up a private enterprise "Svit soli"}

thousand UAH

\begin{tabular}{|c|c|c|c|c|c|c|c|c|c|c|c|c|}
\hline $\boldsymbol{X}$, years & $\boldsymbol{Y}$ & $\boldsymbol{X}_{\mathbf{1}}$ & $\boldsymbol{X}_{\mathbf{2}}$ & $\boldsymbol{X}_{\mathbf{3}}$ & $\boldsymbol{X}_{\mathbf{4}}$ & $\boldsymbol{X}_{\mathbf{5}}$ & $\boldsymbol{X}_{\mathbf{6}}$ & $\boldsymbol{X}_{\mathbf{7}}$ & $\boldsymbol{X}_{\mathbf{8}}$ & $\boldsymbol{X}_{\mathbf{9}}$ & $\boldsymbol{X}_{\mathbf{1 0}}$ & $\boldsymbol{X}_{\mathbf{1 1}}$ \\
\hline $\mathbf{2 0 1 7}$ & $\mathbf{4 6 . 6}$ & 1115.30 & 1116.10 & 47.70 & 2.30 & 1.00 & 20.80 & 2.30 & 112.40 & 1033.00 & 36.00 & 38.00 \\
\hline $\mathbf{2 0 1 8}$ & $\mathbf{5 4 . 0 0}$ & 1651.20 & 1652.80 & 45.10 & 11.50 & 1.00 & 0.00 & 9.20 & 113.70 & 1556.90 & 90.00 & 40.00 \\
\hline $\mathbf{2 0 1 9}$ & $\mathbf{6 3 . 9}$ & 1373.80 & 1376.20 & 33.00 & 13.50 & 120.00 & 0.00 & 2.00 & 109.80 & 1285.90 & 82.80 & 41.55 \\
\hline Total & $\mathbf{1 6 4 . 5}$ & 4140.30 & 4145.10 & 125.80 & 27.30 & 122.00 & 20.80 & 13.50 & 335.90 & 8930.70 & 208.80 & 119.55 \\
\hline Average & $\mathbf{5 4 . 8 3 3}$ & 1380.10 & 1381.70 & 41.93 & 9.10 & 40.67 & 6.93 & 4.50 & 111.97 & 2976.90 & 69.60 & 39.85 \\
\hline
\end{tabular}

According to the analysis of PE "Svit soli", three factors were selected, according to which a general correlation-regression model for the period 2017-2019 was constructed.

$$
\mathrm{Y}=25727+0.60 * 28.1+0.31 * 125.8-0.33 * 3875.8
$$

$Y$ - overall impact factors for 2017-2019.

where, $X_{1}$ - the total value of retained earnings for 2017-2019;

$X_{2}$ - the total value of current commitments for 2017-2019;

$X_{3}$ - the total value of the cost of sales for 2017-2019. 
Kh. P. Danylkiv, N. Ye. Hembarska, V. Ya. Havran, I. I. Hrybyk

Table 2

Characteristics of the economic and mathematical model of PE "Svit soli"

\begin{tabular}{|c|c|c|c|c|}
\hline & $\begin{array}{c}\text { Regression } \\
\text { coefficient }\end{array}$ & Standard error & t-statistics & $P$ \\
\hline Y-intersection & -0.239070812 & 4.611584819 & -0.051841356 & 0.961913891 \\
\hline$X_{11}$ & 1.380278499 & 0.071757711 & 19.23526378 & 0.000306879 \\
\hline
\end{tabular}

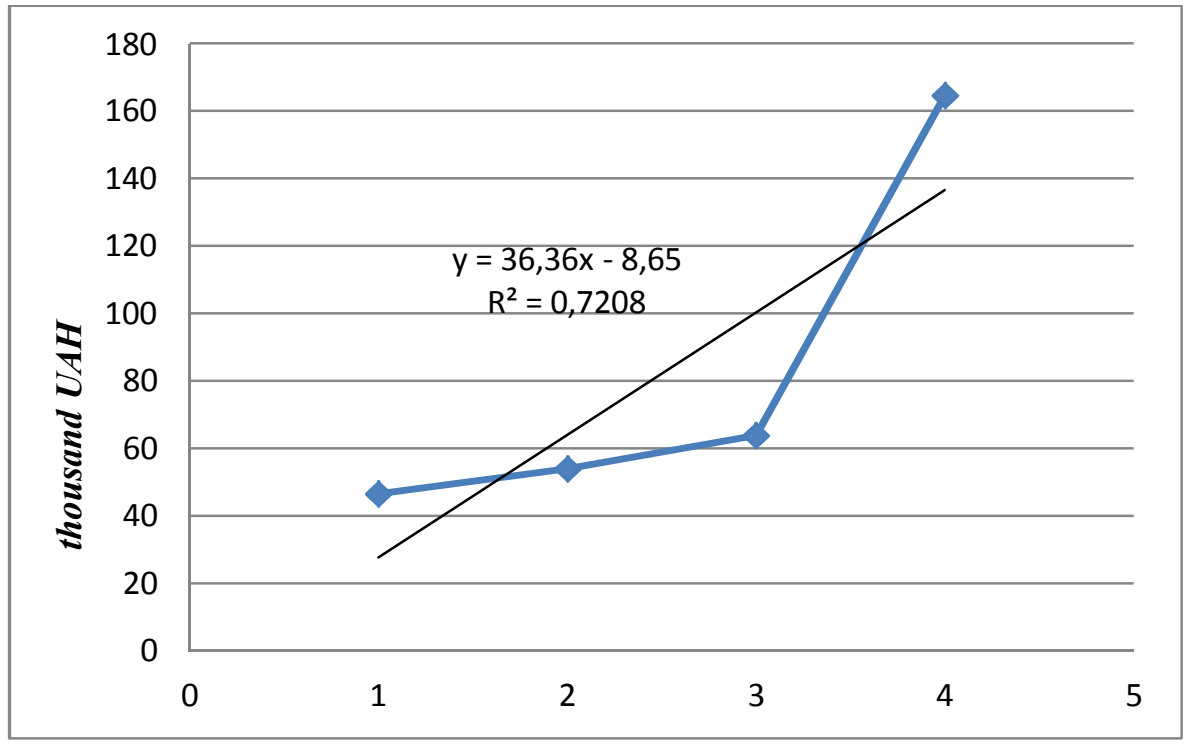

Fig. 1. Correlation between the factors $x$ and $y$ on the performance trait

The values of the parameters $a$ and $b$ of the equation of pair linear regression $\hat{y}=a+b x$, calculated by the formulas [8]:

\begin{tabular}{|c|c|}
\hline$b$ & $a$ \\
\hline 35.580 & -570.87 \\
\hline
\end{tabular}

The regression line equation will look like:

$$
\hat{y}=35.580+(-570.87) x
$$

The correlation coefficient between the variables $x$ and $y$ is calculated by the formula 1 , the solution is made using the sample variance:

$$
\begin{gathered}
r=\frac{\sum_{i=1}^{n}\left(x_{i}-\bar{x}\right) \times\left(y_{i}-\bar{y}\right)}{n \times \sqrt{\bar{x}^{2}-\bar{x}^{2}} \times \sqrt{\overline{y^{2}}-\bar{y}^{2}}} \\
r=1.22
\end{gathered}
$$

The correlation coefficient obtained indicates a strong statistical relationship between the variables.

The coefficient of determination is calculated by the formula:

$$
\begin{gathered}
\mathrm{D}=r^{2} \times 100 \% \\
D=1.48 \%
\end{gathered}
$$


Economic and mathematical modeling of the estimation of efficiency of use of current assets by means of...

The low value of the determination coefficient indicates the small influence of the two variables and, as the value of the determination coefficient shows, $98.52 \%$ of the variability depends on other factors.

To evaluate the adequacy of the accepted econometric model with statistical data, we calculate the Fisher criterion by the formula:

$$
\begin{gathered}
F=\frac{r^{2}}{1-r^{2}} \times \frac{n-m-1}{m} \\
F=-3.06
\end{gathered}
$$

Since, $F>F_{\text {table }}$, it is likely 0.98 that the econometric model is not adequate statistical data.

For the static estimation of the significance of the correlation coefficient, we calculate the Stiudenta criterion by the formula 4 [8]. To find a statistical estimate of the significance of the Stiudenta criterion, we calculate $M r$.

$$
\begin{gathered}
M r=0,781 \\
t=\frac{r}{\frac{\sqrt{1-r^{2}}}{\sqrt{n-m-1}}} \\
t=1,558
\end{gathered}
$$
significant.

Since, $t>t_{\text {table }}$, it is likely that 0.98 the correlation coefficient can be considered statistically

To test the significance of the regression coefficients, we calculate the variance estimates for these parameters:

$$
\begin{aligned}
\sigma_{e}^{2} & =\frac{\sum_{i=1}^{n}(y i-\hat{y})^{2}}{n-2} \\
\sigma_{a}^{2} & =\sigma_{e} \sqrt{\frac{\sum_{i=1}^{n} x_{i}{ }^{2}}{n \sum_{i=1}^{n}\left(x_{i}-\bar{x}\right)^{2}}} \\
\sigma_{b}^{2} & =\sigma_{e} \sqrt{\frac{1}{\sum_{i=1}^{n}\left(x_{i}-\bar{x}\right)^{2}}}
\end{aligned}
$$

\begin{tabular}{|c|c|c|c|}
\hline Indicator & $\sigma_{e}^{2}$ & $\sigma_{a}^{2}$ & $\sigma_{b}^{2}$ \\
\hline Value & 34.8 & 214.40 & 11.53 \\
\hline
\end{tabular}

The observed value of the $t$-criterion is calculated by the formulas:

$$
\begin{aligned}
& t_{a}=\frac{a}{\sigma_{a}} \\
& t_{b}=\frac{b}{\sigma_{b}}
\end{aligned}
$$

\begin{tabular}{|c|c|c|}
\hline Indicator & $t_{a}$ & $t_{b}$ \\
\hline Value & -0.025 & 10.47 \\
\hline
\end{tabular}

The regression parameters are statistically significant and the confidence intervals for the regression equation parameters are:

\begin{tabular}{|c|c|c|}
\multicolumn{3}{c}{$A=a+-a$ at; } \\
$B=b+-a b t$ \\
\hline Indicator & $A$ & $B$ \\
\hline Value & -576.23 & 420.70 \\
\hline
\end{tabular}

$$
-5025.6708<a<-576.23
$$

$2.62<b<420.70$ 


\section{Kh. P. Danylkiv, N. Ye. Hembarska, V. Ya. Havran, I. I. Hrybyk}

Estimated amount of working capital increase:

2020 year $=2,62+(-5025,67) * 2020=-10151$ thousand UAH.

2025 year $=2,62+(-5025,67) * 2025=-10176$ thousand UAH.

2030 year $=2,62+(-5025,67) * 2030=-10202$ thousand UAH.

In order to know how PE "Svit soli" effectively utilize its assets and how the trend towards receivables will change in 2020, it is necessary to forecast its indicators using the least squares method.

The main goal of the least-squares method is to find, by performing a series of algebraic calculations, a theoretical line that would most successfully equalize a number of dynamics.

The equation of the line describing the equalization function is given:

$$
y_{t}=a_{0}+a_{1} t
$$

where, $y_{t}-$ the value of the aligned series of dynamics; $a_{0}, a_{1}-$ parameters of the equation of the line; $t-$ conditional time indicator.

The system of equations for finding the parameters of the equation of the line $\left(a_{0}, a_{1}\right)$ is calculated by the formula:

$$
\left\{\begin{array} { l } 
{ \sum t = 0 } \\
{ \sum y = n a _ { 0 } + a _ { 1 } \sum t } \\
{ \sum y t = a _ { 0 } \sum t + a _ { 1 } \sum t ^ { 2 } }
\end{array} \quad \left\{\begin{array}{l}
\sum y=n a_{0} \\
\sum y t=a_{1} \sum t^{2}
\end{array}\right.\right.
$$

where, $y$ - factual data (current assets, current liabilities); $n$ - number of years.

The intermediate calculations of the trend line parameters $a_{0}, a_{l}$ are shown in Table 3 .

Table 3

\begin{tabular}{|c|c|c|c|c|c|}
\hline Period & $\begin{array}{c}\text { Value, } \\
\text { thousand UAH }\end{array}$ & $t$ & $t^{2}$ & $y^{*} t$ & $\begin{array}{c}\text { Trend, thousand } \\
\text { UAH }\end{array}$ \\
\hline 1 & 2 & 3 & 4 & 5 & 6 \\
\hline II quarter 2017 year & 3200.00 & -5 & 25 & -16000.00 & 2281.74 \\
\hline III quarter 2017 year & 2100.00 & -4 & 16 & -8400.00 & 2643.92 \\
\hline IV quarter 2017 year & 2875.00 & -3 & 9 & -8625.00 & 3006.10 \\
\hline I quarter 2018 year & 3250.00 & -2 & 4 & -6500.00 & 3368.28 \\
\hline II quarter 2018 year & 3625.00 & -1 & 1 & -3625.00 & 3730.46 \\
\hline III quarter 2018 year & 2750.00 & 0 & 0 & 0.00 & 4092.64 \\
\hline IV quarter 2018 year & 5805.00 & 1 & 1 & 5805.00 & 4454.82 \\
\hline I quarter 2019 year & 4515.00 & 2 & 4 & 9030.00 & 4817.00 \\
\hline II quarter 2019 year & 5160.00 & 3 & 9 & 15480.00 & 5179.18 \\
\hline III quarter 2019 year & 6020.00 & 4 & 16 & 24080.00 & 5541.36 \\
\hline IV quarter 2019 year & 5719.00 & 5 & 25 & 28595.00 & 5903.54 \\
\hline I quarter 2020 year & & & & & 6265.72 \\
\hline II quarter 2020 year & & & & & 6627.90 \\
\hline III quarter 2020 year & & & & & 6990.08 \\
\hline IV quarter 2020 year & & & & & 7352.26 \\
\hline Sum & 45019.00 & $\mathbf{0}$ & 110 & 39840.00 & 45019.04 \\
\hline
\end{tabular}

Calculation of estimated values of receivables

Having made the appropriate calculations, we can draw up the trend equation, which is presented as follow

$$
y=4092.64+362.18 * t
$$

On the basis of the obtained data, we will build a trend line of receivables, which reflects the forecasting of indicators for 2020 (Fig. 2). 
Economic and mathematical modeling of the estimation of efficiency of use of current assets by means of...

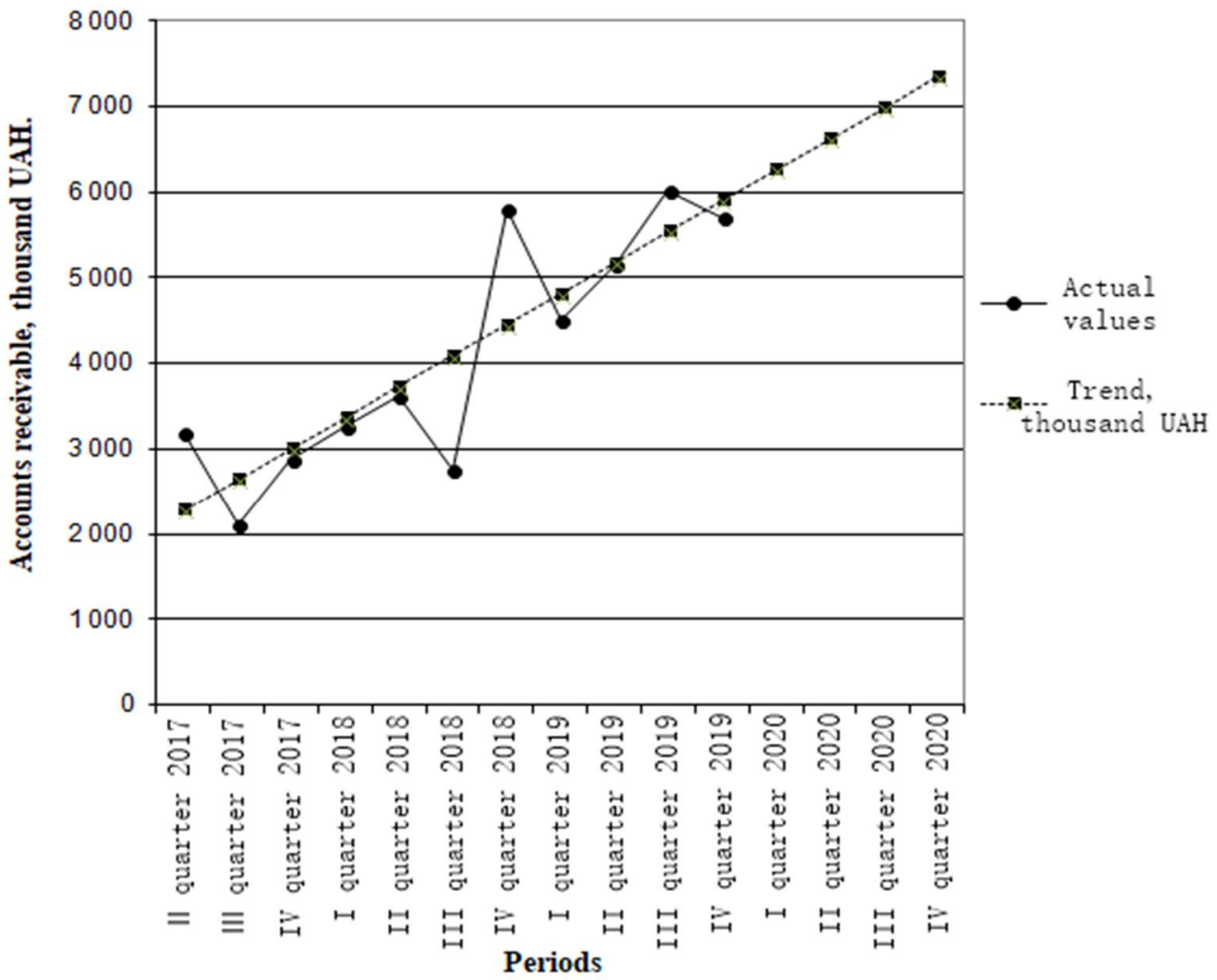

Fig. 2. Estimated changes in receivables

Similarly, we will calculate the estimated values of accounts payable. The results are presented in Table 4.

Table 4

Calculation of estimated values of accounts payable

\begin{tabular}{|c|c|c|c|c|c|}
\hline Period & $\begin{array}{c}\text { Value, } \\
\text { thousand UAH }\end{array}$ & $t$ & $t^{2}$ & $y^{*} t$ & $\begin{array}{c}\text { Trend, thousand } \\
\text { UAH }\end{array}$ \\
\hline II quarter 2017 year & 6848.00 & -5 & 25 & -34240.00 & 6470.97 \\
\hline III quarter 2017 year & 4494.00 & -4 & 16 & -17976.00 & 6918.15 \\
\hline IV quarter 2017 year & 7889.00 & -3 & 9 & -23667.00 & 7365.33 \\
\hline I quarter 2018 year & 8918.00 & -2 & 4 & -17836.00 & 7812.51 \\
\hline II quarter 2018 year & 9947.00 & -1 & 1 & -9947.00 & 8259.69 \\
\hline III quarter 2018 year & 7546.00 & 0 & 0 & 0.00 & 8706.87 \\
\hline IV quarter 2018 year & 10692.00 & 1 & 1 & 10692.00 & 9154.05 \\
\hline I quarter 2019 year & 8316.00 & 2 & 4 & 16632.00 & 9601.23 \\
\hline II quarter 2019 year & 9504.00 & 3 & 9 & 28512.00 & 10048.41 \\
\hline III quarter 2019 year & 11088.00 & 4 & 16 & 44352.00 & 10495.59 \\
\hline IV quarter 2019 year & 10533.60 & 5 & 25 & 52668.00 & 10942.77 \\
\hline I quarter 2020 year & & & & & 11389.95 \\
\hline II quarter 2020 year & & & & & 11837.13 \\
\hline III quarter 2020 year & & & & & 12284.31 \\
\hline IV quarter 2020 year & & & & & 12731.49 \\
\hline Sum & 95775.60 & 0 & 110 & 49190.00 & 95775.57 \\
\hline
\end{tabular}




\section{Kh. P. Danylkiv, N. Ye. Hembarska, V. Ya. Havran, I. I. Hrybyk}

According to the calculated data, the trend equation will look like this:

$$
y=8706,87+447.35 * t
$$

In Fig. 3 presents the values of actual and projected values of accounts payable

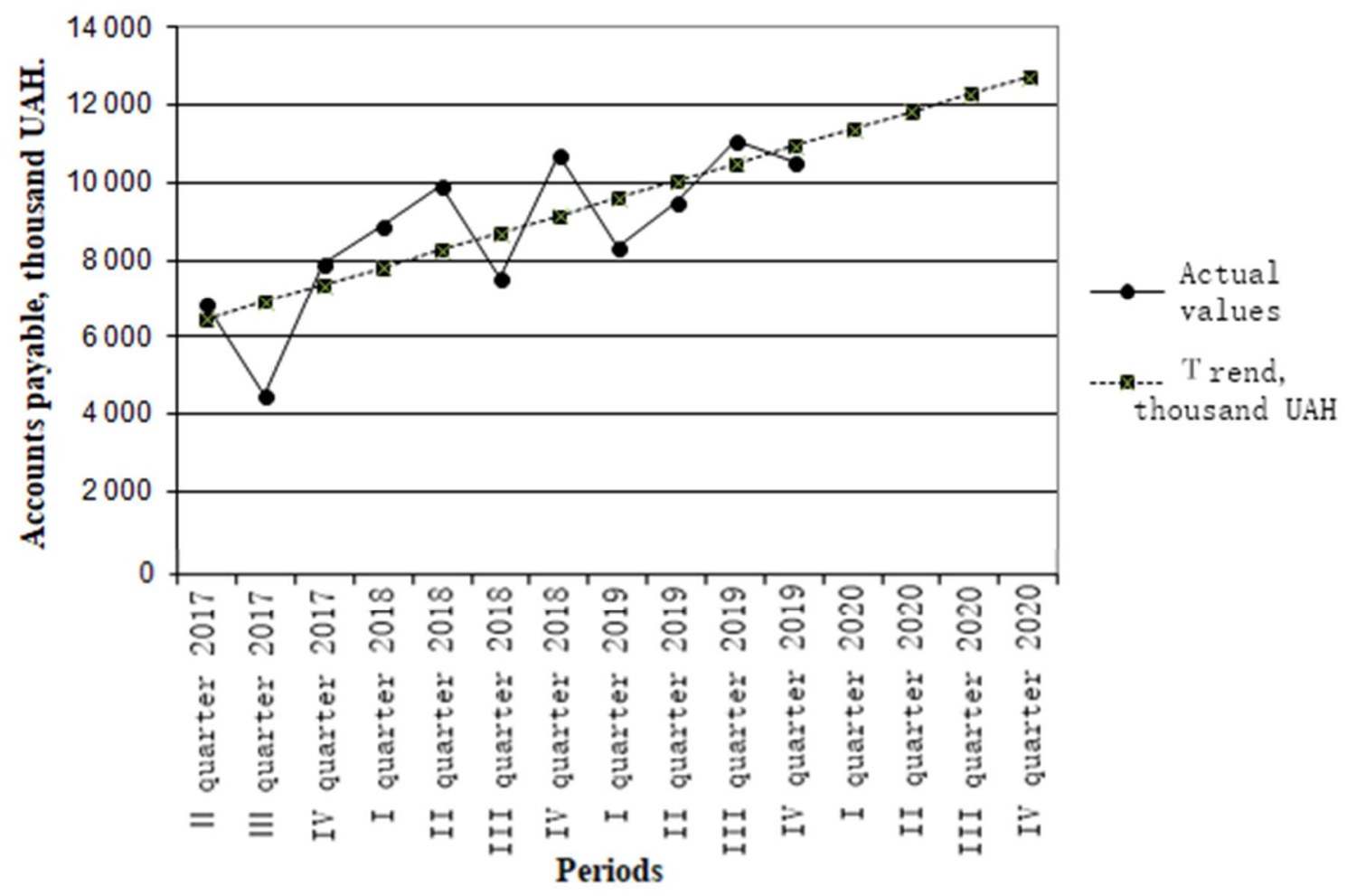

Fig. 3. Factual and trend values of accounts payable

On the basis of calculations, the amount of receivables and accounts payable will increase. Namely, as of January 1, 2020, receivables will amount to UAH 6265.72 thousand, and the amount of accounts payable on the same date will amount to UAH 11389.95 thousand.

The increase in values indicates that the company needs to carry out a set of measures for repayment for the set, namely to develop an effective strategy for return of funds and cooperation on other terms with clients onwards, a similar increase in the accounts payable indicates that the company borrows to increase current assets and increase in liquidity but it is worth noting one aspect that a large amount of borrowing can increase the level of financial independence for the company mizuvaty risk and effectively invest borrowed funds.

\section{Conclusions}

Therefore, a correlation-regression analysis of the relationship between factor and outcome was performed based on the baseline data.

Since the value of the correlation coefficient is 1.22 , this indicates a direct strong statistical relationship between the variables.

The low value of the coefficient of determination (1.48\%) indicates a small influence of the two variables and indicates a high level of $98.52 \%$ of variability, which indicates the dependence on other factors.

Since, $F>F_{\text {table }}(-3.06>1.55)$, it is probable that 0.98 we can assume that according to Fisher's criterion the econometric model is adequate for statistical data.

The calculation of the Student's t test suggests with probability 0.98 that the correlation coefficient is statistically significant. 
Economic and mathematical modeling of the estimation of efficiency of use of current assets by means of...

The correlation of the considered factors will be described by the equation of direct $\hat{y}=35,580+$ $+(-570,87) x$ and the projected volume of current assets will be in 2020 year - -10151 thousand UAH, in 2025 year - -10176 thousand UAH in 2030 year - -10 202 thousand UAH, however, the accuracy of longterm forecasts is not very high.

Therefore, given all the results obtained, the resulting model can be considered adequate and sufficiently accurate.

\section{Prospects for further research}

In further studies, we will explore what change in the efficiency of the use of current assets will contribute to the financial crisis in the enterprise. By means of correlation-regression relationships it is planned to determine the value of the turnover ratios, in which the enterprise is not threatened by the financial crisis. It is planned to develop an approach for correlation-regression analysis of sample from several enterprises. The model may be useful to external users, in particular future investors, to assess the feasibility of investing in businesses.

1. Карачина Н. П., Філатова Н. М., Кочура А. І. (2013). Економічне моделювання формування та використання обігових коштів промислових підприємств // Економічний простір. - № 74. - С. 223-231. Режим доступу: http://nbuv.gov.ua/UJRN/ecpros_2013_74_25.

2. Швецов Ю. Г., Сабельфельд Т. В. Совершенствание методов диагностики финансовой несостоятельности предприятий. Режим доступу: http://cyberleninka.ru/article/n/sovershenstvovanie-metodovdiagnostikifinansovoy-nesostoyatelnosti-predpriyatiy.

3. Вигівська І. М., Іваненко В. О., Шевченко Л. Я. Комплексний аналіз ресурсного потенціалу корпорацій. Режим доступу: http://ven. ztu.edu.ua/article/view/34191/37060.

4. Крюков А. Д. (2012). Дослідження впливу складових оборотних активів підприємства на його фінансові результати на основі кореляційно-регресійного аналізу. Управляння розвитку, № 2. С. 138-140.

5. Теребух А. А., Лісовська Л. С. (2017). Моделі обгрунтування ефективності ухвалення господарських рішень машинобудівних підприємств // Вісник Національного університету “Львівська політехніка”. Серія: Проблеми економіки та управління, № 873, С. 135-145.

6. Ахмерова Х. Ш. Многофакторный корреляционно-регрессионный анализ рентабельности производства. Режим доступу: http://iupr.ru/domains_data/files/zurnal_15/Ahmerova \%20G.Sh.pdf.

7. Білоусова С. В., Ковальчук Т. В. (2018). Економіко-математичне моделювання: компендіум і практикум : навч. посіб. - Київ : Київ. нац. торг.-екон. ун-т. 524 с.

8. Яровий А. Т., Страхов С. М. (2015). Багатовимірний статистичний аналіз : начально-методичний посібник для студентів математичних та економічних фахів. - Одеса: Астропринт, 132 с.

1. Karachyna N. P., Filatova N. M., Kochura A. I. Ekonomichne modeliuvannia formuvannia ta vykorystannia obihovykh koshtiv promyslovykh pidpryiemstv [Economic modeling of formation and use of working capital of industrial enterprises]. Retrieved from: http://nbuv.gov.ua/UJRN/ecpros_2013_74_25.

2.Shvetsov Yu. G., Sabelfeld T. V. Sovershenstvovanye metodov dyahnostyky fynansovoi nesostoiatelnosty predpryiatyi [Improving methods for diagnosing financial insolvency of enterprises]. Retrieved from https://cyberleninka.ru/article/n/sovershenstvovanie-metodov-diagnostiki-finansovoy-nesostoyatelnosti-predpriyatiy/viewer.

3. Vyhivska I. M., Ivanenko V. O., Shevchenko L. Ya. Kompleksnyi analiz resursnoho potentsialu korporatsii [Complex analysis of resource potential of corporation]. Retrieved from http://ven.ztu.edu.ua/article/view/34191 .

4. Kriukov A. D. (2012). Doslidzhennia vplyvu skladovykh oborotnykh aktyviv pidpryiemstva na yoho finansovi rezultaty na osnovi koreliatsiino-rehresiinoho analizu [The increase in the stock of circulating assets of the company for the first financial results on the basis of the correlation-regression analysis]. Upravlinnia rozvytku. Management of development, 2, 138-140.

5. Terebukh A., Lisovska L. (2017). Modeli obgruntuvannya efektyvnosti ukhvalennya hospodars'kykh rishen' mashynobudivnykh pidpryyemstv [Models of justification efficiency of economic decisions making of machinebuilding enterprises]. Bulletin of the National university "Lviv Polytechnic". Series: Problems of Economics and Management, 873, $135-145$. 


\title{
Kh. P. Danylkiv, N. Ye. Hembarska, V. Ya. Havran, I. I. Hrybyk
}

6. Gaydaenko O., Kovalenko L. (2017). Zastosuvannya korelyatsiyno-rehresiynoho analizu dlya prohnozuvannya rezul'tativ diyal'nosti pidpryyemstva [Application of correlation - regression analysis to predict the performance of enterprises]. International collection of scientific works Accounting. Economy. Management: Scientific Notes, Issue 1 (13), $16-23$.

7. Bilousova S. V., Koval'chuk T. V. (2018). Ekonomiko-matematychne modelyuvannya: kompendium i praktykum : navch. posib [Economic and Mathematical Modeling: Compendium and Workshop]. Kyiv : KNTEU, 524.

8. Yarovyy A. T., Strakhov Ye. M. (2015). Bahatovymirnyy statystychnyy analiz : nachal'no-metodychnyy posibnyk dlya studentiv matematychnykh ta ekonomichnykh fakhiv. [Multidimensional Statistical Analysis: A Beginner's Guide to Mathematical and Economic Students]. Odesa: Astroprynt, 132.

Х. П. Данилків, Н. Є. Гембарська, В. Я. Гавран, І. І. Грибик Національний університет “Львівська політехніка"

\section{ЕКОНОМІКО-МАТЕМАТИЧНЕ МОДЕЛЮВАННЯ ЕФЕКТИВНОСТІ ВИКОРИСТАННЯ ОБОРОТНИХ КОШТІВ ЗА ДОПОМОГОЮ КОРЕЛЯЦЙНО-РЕГРЕСІЙНОГО ПІДХОДУ}

\author{
(C) Данилків Х. П., Гембарська Н. С., Гавран В. Я., Грибик I. І., 2020
}

На сучасному етапі економічного реформування, запровадження ринкових методів господарювання зростає потреба в оперативності прийняття управлінських рішень у розрахунку й прогнозуванні варіантів можливих напрямів виробничої діяльності окремих підприємств. А це фактично неможливо здійснити без застосування в аналітичному дослідженні економікоматематичних методів. Найпоширенішим у процесі простого економічного аналізу діяльності економічних систем є використання кореляційно-регресійного аналізу.

У рамках авторського підходу до проведення оцінювання ефективності використання оборотних коштів на ПП "Світ солі" за допомогою кореляційно-регресійного аналізу було виокремлено такі етапи: встановлено форму зв'язку та математичне рівняння зв'язку побудовою графіка кореляційної залежності між роком дослідження (фактор х) i певним статистичним показником (фактор у); обчислено коефіціснт детермінації та коефіціснт кореляції $\mathbf{r}$ i оцінено щільність зв'язку між фактором $x$ i показником у; за критерієм Фішера 3 ймовірністю 0,95 оцінено адекватність прийнятої економетричної моделі статистичним даним; за t-критерієм перевірено статистичну значущість параметрів лінійного рівняння 3 надійністю $P=0,98$; знайдено інтервали довіри для коефіціснтів лінійного рівняння з надійністю $\mathrm{P}=0,98$.

Зважаючи на всі отримані результати ПП “Світ солі" характеризуть як платоспроможне та фінансово стійке підприсмство, яке знаходиться на піку свого розвитку, про що свідчать показники в наступних роках? Для підвищення ефективності показників запропоновані такі заходи: оптимізація організації постачання та системи вибору постачальників; забезпечення оптимального обсягу та структури запасів для забезпечення стабільного виробничого процесу за мінімальних витрат на утримання запасів; прискорення оборотності оборотних активів, зокрема основними шляхами розрахунку обсягу запасів та їх ліквідації; забезпечення сдиної методології щодо організації та ведення обліку окремих складових оборотних активів; впровадження прогресивних технологій i, як наслідок, підвищення ефективності праці; поліпшення організації матеріально-технічного забезпечення та реалізації продукції; оптимізація збутової та кредитної політики.

Ключові слова: ефективність використання оборотних коштів, кореляційно-регресійний аналіз, регресійна модель, лінійна регресія, коефіціснт детермінації, економетрична модель, кореляційна залежність. 